\title{
VESPRÉMSKY BISKUP PETER BERISLO A VESPRÉMSKA DIECÉZNA SYNODA Z ROKU 1515
}

\author{
The Bishop of Veszprém Péter Beriszló and Diocesan Synod \\ of Veszprém in 1515
}

\author{
Dávid Jablonský
}

DOI: 10.17846/CL.2019.12.2.59-68

\begin{abstract}
JABLONSKÝ, Dávid. The Bishop of Veszprém Péter Beriszló and Diocesan Synod of Veszprém in 1515. Péter Beriszló $\left({ }^{\star} 1475-\dagger 1520\right)$ was a prominent church representative who, besides the church sphere, also distinguished himself in political sphere. He used his diplomatic skills, power influence and contacts in the court of Vladislaus II Jagiellon as a diplomat and as a member of the Royal Office and Royal Council. He actively opposed the expansiveness of the Ottoman Empire and took part in the Ottoman-Hungarian wars, which was also fatal to him. Between 1512 and 1520 he was the Bishop of Veszprém. In 1515, as Bishop of Veszprém, he summoned the diocesan synod to Veszprém, where 31 regulations were adopted concerning liturgical discipline and discipline of the clergy. Some regulations were progressive and signalled a Catholic self-reform that was typical after the Council of Trent $(1545-1563)$.
\end{abstract}

Keywords: Bishop, Power, Middle Ages, Synod, Veszprém, Péter Beriszló, Hungary

\begin{abstract}
Abstrakt: JABLONSKÝ, Dávid. Vesprémsky biskup Peter Berislo a vesprémska diecézna synoda $z$ roku 1515. Peter Berislo $\left({ }^{\star} 1475\right.$ - †1520) bol významný cirkevný predstavitel, ktorý sa okrem cirkevnej sféry vyznamenal aj v oblasti politiky. Svoje diplomatické schopnosti, mocenský vplyv a kontakty využil na dvore Vladislava II. Jagelovského ako diplomat i ako člen královskej kancelárie a královskej rady. Aktívne vystupoval proti rozpínavosti Osmanskej ríše a zúčastňoval sa protiosmanských bojov, čo sa mu stalo aj osudným. V rokoch 1512 až 1520 figuroval na poste vesprémskeho biskupa. V roku $1515 \mathrm{z}$ moci tejto funkcie zvolal diecéznu synodu do Veszprímu, kde bolo prijatých 31 nariadení týkajúcich sa oblasti liturgickej disciplinizácie a disciplinizácie kléru. Niektoré nariadenia boli pokrokové a predznamenávali katolícku obnovu (sebareformu), ktorá bola typická až po iniciatíve Tridentského koncilu (1545 - 1563).
\end{abstract}

Klúčové slová: biskup, moc, stredovek, synoda, Vesprém, Peter Berislo, Uhorsko

Peter Berislo sa narodil v roku 1475 v meste Trogir (lat. Tragurium, mad. Trau; dnešné Chorvátsko). Pochádzal z urodzenej rodiny a už v pomerne mladom veku sa dostal na dvor kaločského arcibiskupa Petra Váradiho (1481 - 1501), významného uhorského humanistu. Vdaka diplomatickému úsiliu, mocenskému vplyvu a kontaktom, ktoré časom nadobudol, sa vyznamenal nielen

1 Štúdia vznikla s finančnou podporou projektu VEGA č. 1/0006/18 Imago episcopi - moc biskupa a jej prezentácia $v$ stredoveku. 
na cirkevnom, ale aj na politickom poli. Na budínskom dvore Vladislava II. Jagelovského (1490 1516) sa stal členom královskej rady a vypomáhal pri chode královskej kancelárie. Viedol diplomaciu s Apoštolskou stolicou i s viacerými krajinami vtedajšej Európy. V rokoch 1512 až 1520 bol vesprémskym biskupom a v rokoch 1513 až 1520 chorvátsko-dalmátsko-slavónskym bánom (Kubinyi 1963, 125). Aktívne sa zúčastňoval protiosmanských bojov, čo sa mu napokon stalo osudným. Umrel v roku 1520 pri lokalite Korenica (dnešné Chorvátsko) v dôsledku vojenského stretu s Osmanmi. Jeho telo bolo pochované vo vesprémskom katedrálnom chráme (Nagybakay 1978, 115).

V oblasti synodálnej činnosti je znamenitý jeho krok v podobe zvolania synody vo Vespréme $\mathrm{v}$ roku 1515. Učinil tak z moci vesprémskeho biskupa. Tým využil svoju právomoc na zvolanie diecéznej synody a partikulárne zákonodarstvo v podobe prijatia synodálnych nariadení. Jediným zákonodarcom na diecéznych synodách býval spravidla biskup. On synody zvolával, podmieňoval ich priebeh a zvyšným účastníkom predkladal nariadenia na schválenie, respektíve ich s nimi oboznámil. Bez širšieho priestoru na polemiku či možného zásahu do textovej podoby nariadení (Adriányi 2014, 20).

Príčina, menný zoznam účastníkov ani presný dátum zvolania vesprémskej synody nie sú známe. Široký priestor venovaný liturgickej disciplinizácii a disciplinizácii kléru v nariadeniach ale môže poukazovat na to, že Berislo sa usiloval o morálne povzbudenie duchovných svojej diecézy a unifikovanie pravidiel platných pre oblast liturgie. $\mathrm{V}$ nariadeniach boli obsiahnuté viaceré reformy, ktoré právoplatne nariadil až Tridentský koncil (1545 - 1563). Synodálni účastníci akceptovali celkovo 31 nariadení. Tie boli 11. júna 1517 vytlačené (v podobe knižky formátu quarto) pod názvom Constituciones Sinodales ecclesie Vesprimiensis vo viedenskej tlačiarni, ktorú vlastnil Hieronymus Vietor ( ${ }^{*}$ okolo 1480 - †1546/1547) (Solymosi 1997, 9). Vdaka rozmachu tlače sa čoraz častejšie šírili nariadenia $\mathrm{v}$ diecézach aj $\mathrm{v}$ tlačenej podobe. Napriek tomu je vesprémska synoda z roku 1515 jednou z mála takých predmoháčskych uhorských synod, ktorých nariadenia sú v autentickej tlačenej podobe zachované aj v súčasnosti. V pramennej edícii Karola Péterfiho $\left({ }^{\star} 1790-\dagger 1873\right)$ z 18. storočia (Synodus Vesprimiensis Diocesana 1741, 220-243) boli vesprémske nariadenia $\mathrm{v}$ útržkovitej podobe publikované na základe poškodeného záhrebského rukopisu. V edícii Michala Svoréniho $\left({ }^{\star} 1750\right.$ - †1814) zo začiatku 19. storočia (Syn. Vespr. a. MDXV. 1807, 191-204) bola chýbajúca zložka doplnená o dekréty nitrianskej diecéznej synody z roku 1494, ktoré boli z iniciatívy nitrianskeho biskupa Pavla Bornemisu (1557 - 1579) redigované a vytlačené v roku 1560 vo Viedni. Madarský literárny historik a bibliograf Gedeon Borsa $(1986,72)$ v 80. rokoch minulého storočia natrafil na autentickú tlačenú podobu vesprémskych nariadení v Brne. Ich kritický prepis (doplnený o reprint a úvodnú štúdiu) vydal v roku 1997 László Solymosi (Constitutiones Synodales Ecclesiae Vesprimiensis 1997, 43-107). Do tej doby sa autori opierali len o edície Péterfiho a Svoréniho.

Čo sa týka samotnej obsahovej zložky nariadení, v rovine liturgickej disciplinizácie bolo klerikom nariadené, aby dôkladne rozoznávali omšové modlitby, proroctvá či kánony a listy a evanjeliá predčítavali v správnej podobe. L'ud’om ich mohli podrobne vysvetlovat', čo môže poukazovat' na neskoršiu snahu účastníkov Tridentu o približovanie autentických latinských textov v národných jazykoch (Constitutiones Synodales Ecclesiae Vesprimiensis 1997, 70-71). ${ }^{2} \mathrm{Z}$ radu liturgických (sakrálnych) objektov či priestorov boli v nariadeniach vyzdvihnuté cintoríny. Tie museli byt’ dôkladne ohradené a mali slúžit výhradne na pochovávanie zosnulých (Constitutiones Synodales Ecclesiae Vesprimiensis 1997, 69). Posväcovali sa rovnako ako kostoly či chrámy, vdaka čomu

2 Aj ked' latinčina ostala liturgickým jazykom aj po Tridentskom koncile (1545 - 1563), už počas jeho prvej etapy (1545 - 1548) prišiel jeden z účastníkov (Tommaso Campeggio, biskup z Feltre) s myšlienkou, aby mohli byt národné jazyky využívané aspoň pri čítaniach zo Svätého Písma (Caban 2007, s. p.). 
nadobudli status posvätných liturgických miest. Tam neboli prípustné žiadne hriechy ani profánne činnosti (napr. obchodovanie, praktizovanie remesiel, zábava) (Mihályfi 1937, 222-224). Pri pohrebnej liturgii bolo zdôraznené, aby kňazi odmietali pochovávat kacírov, pohanov, exkomunikovaných (väčšou exkomunikáciou), prekliatych, zosnulých v dôsledku (rytierskych) turnajov, úžerníkov, zbojníkov či lúpežníkov. Bežný laik nemohol byt pochovaný v kostole bez povolenia biskupa, len v tom prípade, ak šlo o významného patróna alebo osobu, ktorá po sebe niečo zanechala na stavbu (správu) kostola (Constitutiones Synodales Ecclesiae Vesprimiensis 1997, 75). V rámci liturgickej disciplinizácie bol vo Vespréme prijatý liturgický kalendár poskytujúci presný obraz o počte (51) a type rozličných sviatkov platných pre Vesprémsku diecézu (pozri prílohu za textom). Popri sviatkoch Pána a sviatočných dňoch venovaných Panne Márii, patrónke Uhorska ${ }^{3}$, bol vymedzený priestor aj pre sviatky mnohých apoštolov, evanjelistov, svätcov, vyznávačov, (proto)mučeníkov a panien. Nechýbali ani sviatky zasvätené biskupom, pápežom či uhorskému panovníkovi Štefanovi I. (1000/1001 - 1038) a Ladislavovi (1077 - 1095) (Constitutiones Synodales Ecclesiae Vesprimiensis 1997, 105-107).

Široký priestor bol v rámci liturgie vyhradený aj pre sviatostnú disciplinizáciu. Prvou sviatostou a predpokladom pre prijatie zvyšných bol krst. Farári za jeho vysluhovanie nemohli požadovat’ žiadne peniaze ani dar. Taktiež nemohli zanechávat' bez krstu žiadne dieta, ktorému hrozilo predčasné úmrtie. Na to mali farárov upozorňovat aj archidiakoni, pričom krst sa nemal oddal'ovat' dlhšie než po dobu ôsmich dní (Constitutiones Synodales Ecclesiae Vesprimiensis 1997, 52-53). Snaha o urýchlenie krstov bola podmienená vysokou detskou úmrtnostou. Niekedy bol preto krst udelený už do niekolkých hodín. V prípade zdravých detí sa spravidla počkalo do prvej nedele. Krstilo sa väčšinou ráno. Dôležitý bol výber vhodných krstných rodičov a evidencia krstených (Schustler 1912, 56-58). Krstit mohol len kňaz alebo biskup. V krajných prípadoch mohli byt' platné aj krsty udelené ženami či heretikmi za predpokladu, že sa pri vysluhovaní dodržiavali platné cirkevné predpisy (Mihályfi 1921, 57). Pri problematike krstného kúpela a hrozbe opakovania krstu bolo prijaté nasledovné: „(...) Ak však také okamžité množstvo vody, ako ani vhodná nádoba na tento účel nie sú $k$ dispozícii, aby mohlo byt' (dieta) úplne ponorené, $z$ malej misky alebo inej nádoby sa nejako naleje množstvo vody na hlavu a telo dietata, ktorému sú venované slová (...) Ak je vskutku pochybnost', že si náhodou krstiaci, ktorého slová sú použité, úplne nepamätá, alebo sa náhodou tí, ktorí boli prítomní, vzájomne búria, potom ten krstí týmito slovami: Ak si pokrstený, neprekrstujem tá, ak ešte nie si pokrstený, ja ta krstím v mene Otca i Syna i Ducha Svätého. Amen (...)“ (Constitutiones Synodales Ecclesiae Vesprimiensis 1997, 53-54).

V nariadení ohladom birmovania bolo zdôraznené, že túto sviatost’ stanovil Ježiš Kristus, ktorý birmoval aj svojich apoštolov. Táto pasáž bola reakciou na učenia niektorých novotárov, ktorí spochybňovali sviatostný charakter birmovania. ${ }^{4}$ Duchovné príbuzenstvo, ktoré vzniklo pri udelení sviatosti medzi birmovancami a krstnými rodičmi (kmotrami) navzájom, bolo prekážkou k uzavretiu právoplatného manželstva. Prijat’ sviatost’ birmovania bez predchádzajúceho krstu nebolo možné a taktiež ju nebolo prípustné prijat viackrát než raz (Constitutiones Synodales Ecclesiae Vesprimiensis 1997, 55). Po vkladaní rúk, pomazaní krizmou a príslušných modlitbách biskupa birmovaná osoba prijímala silu Ducha Svätého (Pohle - Preuss 1915, 277). Látkou sviatosti bola

3 Uhorsko zasvätil Panne Márii panovník Štefan I. Zmienila sa o tom tzv. Väčšia svätoštefanská legenda. Kult Panny Márie v priebehu stredoveku so značnou oblubou uctievali napr. predstavitelia Arpádovskej i Anjouovskej dynastie (Zubko 2014, 25).

4 Skupiny albigencov a valdéncov popierali, že birmovanie má svoj pôvod v božskom nariadení. Martin Luther, Filip Melanchton, Ján Kalvín či iní protestanti namiesto birmovania ustanovili konfirmáciu (ceremónia či druh katechizmu), ktorá symbolizovala formu obnovy prísahy krsteného (Pohle - Preuss 1915, 278-279). 
krizma, biskupom vysvätený olej (lisovaný z olív) miešaný s balzamom alebo rastlinnými živicami vybraných drevín (Magyar Katolikus Lexikon s. a., heslo krizma). Bez prímesí sviatosṫ neprichádzala o patričný účinok a tie boli pridávané len na základe cirkevných nariadení. V prvých storočiach krestanstva sa pod krizmou rozumel iba čistý olej bez prímesí (Mihályfi 1921, 79-80).

Pri problematike sviatosti pokánia bolo príslušné vesprémske nariadenie inšpirované slovami sv. Ambróza ( ${ }^{*}$ okolo 340 - †397). Ten deklaroval, že pri pravom pokání je prítomný zármutok srdca, ústna spoved', úsilie o zadostučinenie a snaha opätovne nezhrešit' (Constitutiones Synodales Ecclesiae Vesprimiensis 1997, 55-56). Pri pokání spovedník odpúštal úprimne olutované a vyznané hriechy spovedajúcej sa osobe. Sviatost' stanovil Kristus, ktorý obdaril právomocou odpúštat’ hriechy najprv svojich apoštolov. Táto právomoc bola viazaná $\mathrm{k}$ rozvahe, kedže kňaz figuroval v úlohe sudcu. Vysluhovanie sviatosti bolo v porovnaní so zvyšnými sviatostami komplikovanejšie. Nestačilo dohliadat' len na formu, látku či účinok sviatosti. Spovedník musel dôkladne vyhodnotit' spoved' a lútost' spolu s hriechmi posudzovat' individuálne (Mihályfi 1921, 124-125).

Pri okruhu Eucharistie (sviatosti oltárnej) bolo duchovným prízvukované, aby ju brali s vážnostou a veriacim ju udel'ovali vlastnoručne. Musela byt̉ uschovaná na dôstojnom mieste v kostole a pre chorlavých a pútnikov mala byt̉ neustále $\mathrm{k}$ dispozícii. Kňaz odetý v superpelícii a štóle ju prinášal na oltár v cibóriu pokrytom bielym plátnom na znamenie zvona a pri svietiacom svetle (horiacich sviečkach) (Constitutiones Synodales Ecclesiae Vesprimiensis 1997, 59-60). V príslušnom vesprémskom nariadení sa nevenovala širšia pozornost̉ spôsobu vysluhovania Eucharistie veriacim. Platil tradičný (katolícky) úzus pod spôsobom chleba. O niekolko rokov sa na podnet protestantských myšlienok spôsob vysluhovania pod obojakým spôsobom postupne rožsiroval už aj v Uhorsku. Laikov a necelebrujúcich duchovných pritom k prijímaniu pod obojakým spôsobom podla katolíckej cirkvi nezaväzovalo žiadne božské prikázanie a Kristus sa prijímal celý aj pod spôsobom chleba. Poznatok, že Kristus vysluhoval sviatost’ oltárnu apoštolom pri poslednej večeri pod spôsobom chleba i vína ešte automaticky neznamenalo, že tým smeroval rovnaké ustanovenie aj veriacim (Dokumenty Tridentského koncilu 2015, 151-153).

Vo vesprémskom nariadení spätom so sviatostou posledného pomazania boli obsiahnuté slová apoštola Jakuba (*? - †43): „(...) kto je spomedzi vás slabý, cirkev (mu) privedie kňazov a pomazávajúc ho olejom sa nad ním modlia v mene Pána, a modlitba slabého veriaceho uzdraví, a ak je $v$ hriechoch, odpustite mu ich. Slabí sú preto navštevovaní a nemocných oddane pomazávate olejom (...)“(Constitutiones Synodales Ecclesiae Vesprimiensis 1997, 61). Pri sviatosti posledného pomazania (pomazania chorých) kňaz pomazával vážne chorú osobu a modlil sa nad ňou. Vdaka tomu sa uzdravila jej duša a v optimálnom prípade i telo. Podla svedectva evanjelistu Marka $\left({ }^{*} ?-\dagger 68\right)$ už aj samotní apoštoli vyháňali z ludí démonov a pomazávali chorých olejom. Apoštol Jakub bol presvedčený o tom, že aj túto sviatost̉ stanovil Kristus, kedže apoštolov k činnosti pomazávania chorých vyzval práve on. O sviatostnom charaktere posledného pomazania bol presvedčený aj sv. Augustín ( $\left.{ }^{*} 354-\uparrow 430\right)$, pápež Inocent I. (401 - 417), sv. Atanáz ${ }^{\star} 296$ - †373), sv. Ján Zlatoústy ( ${ }^{*}$ okolo 340 až 350 - †407), Origenes ( ${ }^{*}$ okolo 184 - †okolo 253) či sv. Hypacius (4. storočie). Látkou sviatosti sa stal olej lisovaný z olív posvätený biskupom. Pri udelovaní sviatosti bolo dôležité, aby sa pomazávalo olejom vysväteným výhradne na tento účel (oleum infirmorum) a nie olejom katechumenov alebo krizmou (Müller 1928, 7-9; Mihályfi 1921, 275-279).

Pri sviatosti kňazstva (svätenia kňazstva, posvätného stavu) synodálni účastníci akceptovali nasledujúce nariadenie: „Šiesta sviatost' (je tá), skrz ktorú sa ordinovanému odovzdáva duchovná moc a úrad. Jestvujú teda menovite kñazské svätenia ostiára, lektora, exorcistu, akolytu, subdiakona, diakona a kňaza, ku ktorým kanonisti pripájajú žalmistov k prvému a biskupstvo k poslednému, ktoré oba tiež sami radia k duchovnému stavu. A ustanovuje sa táto sviatost', pretože v jej prijímaní je posvätná vec, je to odovzdanie milosti, ktorá formuje to, ako sa (ordinovaní) prejavujú (vo svojom úrade). Tie tri posledné a štvrtú menujú biskupi nepochybne posvätnou rozvážnostou (podla 
toho), do akej miery (ordinovaní) preukazujú čistotu a zdržanlivost' (...)“ (Constitutiones Synodales Ecclesiae Vesprimiensis 1997, 62-63). ${ }^{5} \mathrm{Na}$ získanie svätenia, predovšetkým v prípade vyšších svätení, bolo nutné splnit viacero podmienok. Popri morálnych či etických zásluhách a vzornom živote sa prihliadalo aj na legitímny (manželský) pôvod, predpísaný vek či adekvátne vzdelanie. Vo Vespréme preto prijali dalšie nariadenie, ktoré adeptom na svätenie prikazovalo, aby sa aspoň tri dni pred povýšením do príslušného duchovného stupňa ukázali miestnemu biskupovi a skúšajúcim. Tí mali dôkladne preskúšat jeho spôsobilost' a overit’ spomínaný vek, mravy či pôvod (Constitutiones Synodales Ecclesiae Vesprimiensis 1997, 83).

V súvislosti so sviatostou manželstva bolo nariadené, aby sa dôkladne rozlišovalo medzi zásnubami (príslubom na uzavretie manželstva v budúcnosti) a manželstvom (právoplatným nerozlučným spojením života muža a ženy formou sviatosti). Dievčatá sa mohli v Uhorsku v období konania vesprémskej synody legitímne vydávat ako dvanástročné a muži ženit', ked’ dosiahli štrnásty rok života. Pokrokovou iniciatívou účastníkov vesprémskej synody bol zákaz uzatvárania tajných manželských zväzkov (matrimonium clandestinum), kedže ich definitívny zákaz nariadil až Tridentský koncil. Aby sa vo Vesprémskej diecéze predchádzalo akýmkolvek prekážkam pri uzatváraní plánovaných manželstiev, kňazi mali veriacich dopredu informovat’ o plánovanom akte podla predpísaného vzoru (ohlášky). Museli vyhlásit meno ženícha a jeho otca, ako i lokalitu, z ktorej pochádzali. Podobne aj meno nevesty a jej otca a lokalitu, kde bývali. Ak mal niekto námietky, mohol predstúpit' a kňazovi predložit svoju odôvodnenú námietku (Constitutiones Synodales Ecclesiae Vesprimiensis 1997, 64,68). Sviatosṫ manželstva sa od ostatných sviatostí odlišovala $\mathrm{v}$ tom, že kým forma, látka a účinok zvyšných sviatostí bola stanovená Ježišom Kristom (i ked' predobraz niektorých sviatostí je spozorovatelný už aj v textoch Starého zákona), Kristus povýšil $\mathrm{v}$ tomto prípade na úroveň sviatosti manželskú zmluvu. Jestvujúci inštitút s tradíciami a právnym základom. Rozdiel bol aj vo vysluhovaní sviatosti. Prítomnost̉ kňaza pri uzavieraní manželského aktu bola síce predpísaná cirkvou. Kňaz pri tom ale pôsobil skôr ako dôveryhodný svedok vyslaný cirkvou. Muž a žena tým činom sviatost' nielen prijímali, ale si ju aj vzájomne vysluhovali (Mihályfi 1921, 352-353).

Po uvedení jednotlivých sviatostí a pravidiel spätých s ich vysluhovaním bolo akceptované aj nariadenie, ktoré slúžilo na tzv. ochranu sviatostí: „Nasledovne by ste mali velebit znalost', ktorá spočiva $v$ obozretnej ochrane sviatostí. Nepustite teda žiadnu ženu posluhovat' $k$ oltáru alebo siahat' na Pánov kalich (...) Nad oltárom nestrpíte umiestnené nič, iba puzdrá, relikvie a tiež kríže, a tu potrebné modlitebné knižky, svietniky a cibóriá pre Pánovo telo. Učebné knižky máte postačujúce. Posvätné nádoby čistíte a utierate vlastnými rukami (...)“ (Constitutiones Synodales Ecclesiae Vesprimiensis 1997, 69).

Obsiahle nariadenia boli vo Vespréme akceptované aj v rovine disciplinizácie kléru. Dôraz sa kládol na výzor a odev klerikov, ktorí museli prijat tonzúru a nosit čo najmenej pruhované či

5 Ostiár vlastnil klúče od kostola a ten otváral a zatváral. Dohliadal na jeho vnútro a exteriér a nevpúštal dovnútra exkomunikované osoby. Lektor prednášal čítania a kázal pre ludí proroctvá. Exorcista mal za úlohu ovládat texty exorcizmov a vystieral ruky nad egumenmi a katechumenmi pri exorcíciách. Akolyta pripravoval osvetlenie vo svätyniach, prinášal vosk a pripravoval pódium pre sviatost’ oltárnu. Subdiakon prinášal k oltáru kalich a paténu a poskytoval ich kňazom. Biskupom a kňazom podával vodu k umývaniu rúk. Diakon pomáhal kňazom; slúžil pri vysluhovaní sviatostí; staral sa o dary patriace na oltár a kríz a čítal evanjelium či skutky apoštolov. Kňaz vysluhoval Eucharistiu; prednášal modlitby a požehnával Božie dary. Biskup vysväcoval kostoly, pomazával oltáre, posväcoval krizmu, ordinoval adeptov na duchovné svätenia. Žalmista sa staral o spevy, požehnania, chvály, obety či odpovede. Po Tridente sa svätenia delili do dvoch skupín. Medzi menšie svätenia (ordines minores) patrili ostiári, lektori, exorcisti a akolyti. Medzi vyššie svätenia (ordines maiores; ordines sacri) diakoni, kňazi a biskupi. Úrad subdiakona bol akýmsi medzistupňom, resp. predstupňom k vy̌ším sväteniam (Rábik 2014, 22-24). 
rôznofarebné rúcha (Constitutiones Synodales Ecclesiae Vesprimiensis 1997, 80). Spôsob odievania a vizuálna stránka jedinca v stredoveku i novoveku predstavovali klúčový odlišovací prvok. Tvar, použitá látka a farba šiat poukazovali na spoločenské postavenie, vek, pohlavie, rodinný stav či príslušnost’ k spoločenskej vrstve. Nikto sa nemohol obliekat mimo rámca svojho postavenia (Deák 2014, 150).

Duchovní museli oddane spravovat svoje úrady a benefíciá. ${ }^{6}$ Nikto z Vesprémskej diecézy nemohol bez súhlasu biskupa odovzdávat benefíciá či kostoly svetským predstavitelom, $\mathrm{v}$ opačnom prípade hrozil trest exkomunikácie. Exkomunikovaní mohli byt aj tí duchovní, ktorí sa vo svojich úradoch a benefíciách neukázali dlhšie než po dobu šest’ mesiacov. Predstavitelia Vesprémskej diecézy smeli obsadzovat' len také kostoly či benefíciá, ktoré sa nachádzali na území diecézy. Kňazi sa museli vyhýbat simónii (kupovaniu cirkevných úradov za peniaze). Úrad zabezpečený formou kúpy nebol platný a hrozila strata benefícia. Cirkevní predstavitelia sa nesmeli zapájat ani do verejných trhov či obchodovania. Pre klerika to bolo nedôstojné, rovnako ako úžera. V nariadeniach padol argument, že kým niektoré osoby úžera obohacuje, iní strácajú svoje majetky. Osoby hromadiace zisk mali byt na základe (biskupského) vyšetrovania obvinené a odsúdené z podvádzania a klamstva. Varovaní boli všetci kazatelia či spovedníci, aby sa, rešpektujúc kanonické právo, takýchto aktivít nedopúštali (Constitutiones Synodales Ecclesiae Vesprimiensis 1997, 73, 82, 85-86, 88-89, 96). Všeobecná vôla (krestanskej) cirkvi o elimináciu nekalých finančných praktík bola prejavená napr. už na II. lateránskom koncile (1139) prostredníctvom kánonu 24, ktorý zakazoval požadovat peniaze za krizmu, olej alebo pohreb. Rovnako na III. lateránskom koncile (1179) pomocou kánonu 7, ktorý zakazoval vyberat poplatky za dosadzovanie biskupov, opátov prípadne kňazov do príslušných úradov; pohreby, manželstvá alebo zvyšné sviatosti. Problematike simónie sa napokon podrobne venovali aj účastníci IV. lateránskeho koncilu (1215) v kánonoch 63 až 66 (Schroeder 1937, 211, 221, 288-289).

Osoby vyberajúce poplatky pri prechode cez mosty ich nesmeli požadovat’ od svetských ani reholných klerikov, len v tom prípade, ak bol poplatok spätý s dovezeným tovarom alebo bol určený pre synodu či mýtnu stanicu. Kvôli ochudobňovaniu biskupských a kapitulárnych pokladníc bolo prízvukované, aby nikto nezabúdal na splatenie desiatkov. Boli to povinné cirkevné poplatky prameniace v božskom nariadení. Ak sa ich plateniu niekto napriek upozorneniam vyhol, mohol byt potrestaný exkomunikáciou. Pri exkomunikácii sa rozlišovali dva typy: väčšia a menšia. Väčšou boli potrestané závažné hriechy a priestupky voči cirkvi. Menšia mala dosah na osoby, ktoré už boli potrestané väčšou exkomunikáciou a napriek tomu sa zúčastnili bohoslužieb alebo prijali nejakú sviatost'. Exkomunikácia bola vel’mi vážnym cirkevným trestom, archidiakoni preto museli pozorne sledovat', či exkomunikované osoby náhodou neprijímajú alebo neudelujú duchovné svätenia (Constitutiones Synodales Ecclesiae Vesprimiensis 1997, 76-77, 84-86).

V rovine morálky, príkladného správania a dodržiavania celibátu bolo klerikom zakázané, aby sa zdržiavali so ženou, ktorá nepreukazovala zdržanlivé správanie alebo s nimi nebola pokrvne príbuzná. Klerik sa musel vyhýbat' aj popíjaniu či nedôstojnému vyspevovaniu (Constitutiones Synodales Ecclesiae Vesprimiensis 1997, 80, 87-88). Jedna z definícií charakterizovala celibát ako večnú pohlavnú zdržanlivost', ku ktorej viazalo predstavitel’ov vyššieho duchovenstva (západnej cirkvi) cirkevné právo. Po prijatí vysviacky sa vyšší duchovný nemohol viac oženit. Ak by sa nejakým spôsobom pokúsil vstúpit do manželstva, zväzok by bol neplatný. Ak chcel prijat vysviacku ženatý muž, $\mathrm{z}$ manželstva musel vystúpit', manželku zanechat' a odprisahat večnú zdržanlivost’ on i jeho žena (Zsigovits 1914, 3). Ďalšia definícia opisovala cirkevný celibát (caelebs = slobodný,

6 Benefícium bolo trvalé právo cirkevného predstavitela na obsadenie vybraného cirkevného úradu, funkcie či majetku, z čoho vyplývalo aj spravovanie finančného výnosu plynúceho z daného úradu (Magyar Katolikus Lexikon s. a., heslo egyházi javadalom). 
bez manželstva) ako neženatost', v ktorej je obsiahnutá aj pohlavná zdržanlivost'. V takomto poňatí celibát vylučoval manželský zväzok i všetky pohlavné aktivity. Celibát sa týkal všetkých diakonov, kňazov a biskupov, pričom od II. vatikánskeho koncilu (1962-1965) diakoni tvorili výnimku (za predpokladu, že prijali svätenie ako ženaté osoby v dospelom veku) (Denzler 2000, 15).

Otázka celibátu, pohlavnej zdržanlivosti, mileniek alebo manželiek vyššieho duchovenstva bola preberaná na viacerých stredovekých konciloch. Napr. 3. kánon I. lateránskeho koncilu (1123) zakazoval, aby kňazi, diakoni či subdiakoni udržiavali manželky alebo konkubíny, resp. vo svojich príbytkoch prebývali s osobami ženského pohlavia, ktoré odsudzoval už 3. kánon I. nicejského koncilu z roku 325. Výnimku tak tvorili iba matky, sestry, tety, prípadne ženy, ktoré neboli podozrivé z toho, že by kňaza zviedli. 21 kánon I. lateránskeho koncilu zakazoval, aby vyšší klerici uzatvárali manželstvá a v prípade, že figurovali v manželstve, takýto zväzok mal byt' rozpustený. 6. kánon II. lateránskeho koncilu (1139) prikazoval, aby boli tí nositelia vyšších svätení, ktorí mali milenky alebo mali uzatvorené manželstvá, prepustení zo svojich benefícií a úradov. Na to nadväzoval aj 7. kánon identického koncilu, ktorí veriacim nariadoval, aby sa nezúčastňovali bohoslužieb, ktoré celebrovali takéto osoby. K pohlavnej zdržanlivosti a disciplíne kléru napokon vyzýval aj 14 kánon IV. lateránskeho koncilu (1215) (Schroeder 1937, 180, 192-193, 200-201, 255-256).

Pri okruhu závetov bolo zdôraznené, aby sa neprávom nadobudnutý majetok po smrti jedinca odovzdal najneskôr do šiestich mesiacov právoplatnému dedičovi. Ak sa tak nestalo, hrozil za to trest exkomunikácie. Pri zostavovaní testamentu bolo dôležité, aby bol podpísaný za asistencie notára alebo kňaza a v prítomnosti minimálne troch svedkov (Constitutiones Synodales Ecclesiae Vesprimiensis 1997, 91). Závet odzrkadluje historický prameň, ktorý predstavuje duchovné svedectvo o období, v ktorom vznikol. Závety nebrali do úvahy iba materiálnu stránku alebo pomery, ktoré vyjadroval poručitelom. Rovnako odrážali aj náboženskú či duchovnú rovinu. Jedinec vyjadrujúci vlastné svedectvo sa pomocou testamentu pripravoval na život, ktorý ho čakal po smrti, lúčil sa so svojimi rodinnými príslušníkmi a niečo im odkázal. Vyjadril tak túžbu po spáse svojej duše a nekonečnom živote (Nemeš 2009, 151).

Aby mali nariadenia prijaté na vesprémskej diecéznej synode v roku 1515 svoj účinok aj v náboženskej praxi, bolo dôležité, aby sa s nimi oboznámilo čo najviac duchovných. A to nielen prostredníctvom neskoršej tlačenej podoby, ale priamo na synode. Práve preto nebolo ideálne, ak sa na synodu nedostavili všetky pozvané osoby a svoju neprítomnost' nevedeli rozumne zdôvodnit'. V dôsledku toho bolo na synode prijaté nariadenie, ktoré všetkým absentérom pod hrozbou exkomunikácie prikazovalo, aby sa do pätnástich dní od konania synody dostavili pred vesprémskeho biskupa Petra Berisla, prípadne generálneho vikára, a predostreli príčinu svojej neprítomnosti. Ak by tak absentéri neučinili, prípadne by voči biskupovi alebo vikárovi postupovali neprimeraným spôsobom, mohli byt' opätovne exkomunikovaní.

Vesprémska diecézna synoda z roku 1515 bola spolu so svojimi nariadeniami dôkazom reformných aktivít a teologickej erudovanosti Petra Berisla, ktorý svoje schopnosti zúročil vo viacerých rovinách a ako vesprémsky biskup bol oporou svojej diecézy. V niektorých nariadeniach boli obsiahnuté zmeny, ktoré právoplatne nariadili konciloví otcovia Tridentu skoro o polstoročie neskôr. Prísna disciplinizácia na poli liturgie a morálky klerikov poukazuje na snahu o katolícku sebareformu na území vlastnej diecézy, na ktorú sa niektoré diecézy nezmohli ani po Tridentskom koncile. Prijatie nariadení v náboženskej praxi môže byt’ na základe chýbajúcich prameňov síce otázne. Synodálne nariadenia však boli právne povinnými a všeobecne platnými normami, ktorých sa musel pridržiavat každý jeden duchovný a veriaci diecézy. Počet i obsahová stránka

SOLYMOSI 1997, 91; r. 1198-1210. 
vesprémskych nariadení skrz takúto prizmu preto museli byt prínosné a pre klérus i veriacich Vesprémskej diecézy hodnotné a podnetné.

\section{REFERENCES}

Adriányi, Gábor. 2014. A római katolikus egyház zsinatai. In Balogh, Margit - Varga, Szabolcs Vértesi, Lázár (eds.). Katolikus zsinatok és nagygyülések Magyarországon a 16.-20. században. Budapest - Pécs, 13-26.

Borsa, Gedeon. 1986. Hazai egyházmegyék Mohács előtti nyomtatott zsinati határozatai. In Magyar könyvszemle 102/1, 67-74.

Caban, Peter. 2007. Medzi Tridentom a Druhým Vatikánom. In Impulz 3/1, s. p.

http://www.impulzrevue.sk/article.php?181.

Constitutiones Synodales Ecclesiae Vesprimiensis. 1997. In Solymosi, László (ed.). A veszprémi egyház 1515. évi zsinati határozatai. Budapest, 43-107.

Deák, Éva. 2014. Öltözködés és identitás a 17.-18. századi Erdélyben a viseletsorozatok tükrében.

In Korall Társadalomtörténeti Folyóirat 15/55, 150-168.

Denzler, Georg. 2000. Dějiny celibátu. Brno.

Dokumenty Tridentského koncilu. 2015. Hrdina, Ignác Antonín (ed.). Dokumenty Tridentského koncilu. Praha.

Kubinyi, András. 1936. Beriszló Péter és Budai szereplése. In Gerevich, László (ed.) Budapest régiségei. A Budapesti Történeti Múzeum évkönyve XX. Budapest, 125-136.

Magyar Katolikus Lexikon. s. a. Magyar Katolikus Lexikon kísérleti internetes változata. s. 1. http://lexikon.katolikus.hu/.

Mihályfi, Ákos. 1921. Az emberek megszentelése. Egyetemi előadások a lelkipásztorkodástan köréből. Budapest.

Mihályfi, Ákos. 1937. Verejné bohoslužby. Katolícka liturgika. I. diel. Banská Bystrica.

Müller, Lajos. 1928. Az utolsó kenet. Budapest.

http://www.ppek.hu/konyvek/Muller_Lajos_Az_utolso_kenet_1.pdf.

Nagybakay, Péter. 1978. Beriszló Péter veszprémi püspök címeres sírköve. In Kralovánszky, Alán Palágyi, Sylvia (eds.). A Veszprém Megyei Múzeumok Közleményei 13. Történelem. Veszprém, 113-132.

Nemeš, Jaroslav. 2009. Testament bratislavského kanonika Gašpara Romera z roku 1517 a jeho ekonómia spásy. In Nemeš, Jaroslav - Papajík, David (eds.). Ružomberský historický slovník III. Ružomberok, 150-172.

Pohle, Joseph - Preuss, Arthur. 1915. The Sacraments. A Dogmatic Treatise. Volume I. St. Louis.

Rábik, Vladimír. 2014. Monumenta Vaticana Slovaciae. Tomus IV. Camera apostolica 1 (Libri formatarum 1425 - 1524). Trnavae - Romae.

Schroeder, Henry Joseph. 1937. Disciplinary Decrees of the General Councils. Text, translation, and commentary. St. Louis - London.

Schustler, Emília. 1912. Magyar társadalmi és családi élet 1570-1600-ig. Budapest.

Solymosi, László. 1997. A veszprémi egyház 1515. évi zsinati határozatai. Budapest.

Syn. Vespr. a. MDXV. 1807. In SZVORÉNYI, Michaelus (ed.). Synopsis critico-historica decretorum synodalium pro ecclesia hungaro-catholica editorum. Vesprimii, 191-204.

Synodus Vesprimiensis Diocesana. 1741. In Péterffy, Carolus (ed.). Sacra Concilia Ecclesiae romano-catholicae in Regno Hungariae. Vol. I. Posonii.

Zsigovits, Béla. 1914. A papi nőtlenség (coelibatus) története Magyarországon. Budapest. 
Zubko, Peter. 2014. Mariánske sviatky latinskej cirkvi s prihliadnutím na územie Slovenska. In Žeňuch, Peter - Zubko, Peter (eds.). Bohorodička v kultúrnych dejinách Slovenska. Bratislava, 22-55.

\begin{abstract}
SUMMARY: THE BISHOP OF VESZPRÉM PÉTER BERISZLÓ AND DIOCESAN SYNOD OF VESZPRÉM IN 1515. Péter Beriszló has distinguished himself through several activities during his church and political career. In his position of Bishop of Veszprém (1512 - 1520) he convened the diocesan synod in Veszprém (1515), where 31 significant regulations were accepted and then published in 1517. From the field of liturgical discipline were adopted regularities related to worship and prayer; liturgical objects (cemeteries); the funeral liturgy and liturgical calendar. However, the focus of regulations was on the sacramental discipline and elaboration of the conditions for the service of the seven sacraments in the form of baptism, confirmation, the sacrament of penance, the Eucharist, the last anointing, the sacrament of priesthood and the sacrament of marriage. For the service of the sacraments, the priest could not demand money, nor gifts; sacraments had to be served with prudence and respect. The children were to be baptized as soon as possible and the Eucharist for the sick or pilgrims should always be present in the churches. In the case of the sacrament of the priesthood, the morals, education, age and legitimate marital origin of the candidates had to be taken into consideration. From the point of view of the sacrament of marriage, care was taken to distinguish between engagement and marriage and secret marriages (matrimonium clandestinum) were strictly forbidden. In the sacrament of confirmation and the last anointing, it was important to distinguish between chrism and other holy oils. The priest had to approach the sacrament of penance responsibly. He had to treat the liturgical vessels with respect and keep them clean. In clergy discipline an emphasis was placed on the clothing of the clerics and the wearing of tonsure. Clerics should have avoided simony, they should take care of their offices and benefices, and avoiding trading and participating in secular markets. Tithes were to be paid in full and on time. Two types of excommunications (greater and lesser) were specified. An emphasis was also placed on strict celibacy which was discussed thoroughly and in detail. For testaments, it was important that the inheritances were handed over to the rightful heirs within 6 months. Finally, in order to spread the regulations efficiently, the synod required attendance of all those who were invited to come and the absentees were warned to arrive within 15 days to apologize and explain their absence. In conclusion, the synod was certainly beneficial and rich in its content. It evidenced to an effort to improve the condition of the clergy in the field of discipline and morality and it testified to the importance of the unification of worship and liturgical actions.
\end{abstract}

Mgr. Dávid Jablonský, PhD.

University of Ss. Cyril and Methodius

Faculty of Arts

Department of Historical Sciences and Central European Studies

Námestie J. Herdu 2

91701 Trnava

Slovakia

david.jablonsky@ucm.sk 


\section{Prílohy/Appendix}

Liturgický kalendár prijatý na vesprémskej synode v roku 1515 / Liturgical calendar adopted at the Veszprém synod of 1515

\begin{tabular}{|c|c|c|c|}
\hline Sviatok & Dátum & Sviatok & Dátum \\
\hline Obriezka Pána & 1. január & Premenenie Pána & 6. august \\
\hline Zjavenie Pána & 6. január & Mučeník Vavrinec & 10. august \\
\hline Obrátenie sv. Pavla & 25. január & Nanebovzatie Panny Márie & 15. august \\
\hline Očistovanie Panny Márie & 2. február & Král’ Štefan & 20. august \\
\hline Apoštol Matej & 24. február & Apoštol Bartolomej & 24. august \\
\hline Pápež Gregor & 12. marec & Biskup a vyznávač Augustín & 28. august \\
\hline Zvestovanie Panny Márie & 25. marec & Narodenie Panny Márie & 8. september \\
\hline Biskup a vyznávač Ambróz & 4. apríl & Povýšenie svätého Kríža & 14. september \\
\hline Mučeník Juraj & 24. apríl & Apoštol a evanjelista Matej & 21. september \\
\hline Evanjelista Marek & 25. apríl & Archanjel Michael & 29. september \\
\hline Sviatok zmŕtvychvstania Pána & marec/apríl & Hieronym presbyter & 30. september \\
\hline Nanebovstúpenie Pána & marec/apríl & Lukáš evanjelista & 18. október \\
\hline Turice & marec/apríl & Apoštoli Šimon a Júda & 28. október \\
\hline Sviatok Svätej Trojice & marec/apríl & Sviatok Všetkých svätých & 1. november \\
\hline Najsvätejšie Kristovo Telo & marec/apríl & Biskup a vyznávač Martin & 11. november \\
\hline Filip a Jakub & 1. máj & Alžbeta vdova & 19. november \\
\hline Povýšenie svätého Kríža & 3. máj & Katarína panna & 25. november \\
\hline $\begin{array}{l}\text { Zjavenie sa svätého archanjela } \\
\text { Michaela }\end{array}$ & 8. máj & Apoštol Ondrej & 30. november \\
\hline Ján Krstitel' & 24. jún & Vyznávač Mikuláš & 6. december \\
\hline Král'Ladislav & 27. jún & Počatie Panny Márie & 8. december \\
\hline Apoštoli Peter a Pavol & 29. jún & Apoštol Tomáš & 21. december \\
\hline Návšteva Panny Márie & 2. júl & Narodenie Krista & 25. december \\
\hline Panna Margaréta & 13. júl & Protomučeník Štefan & 26. december \\
\hline Mária Magdaléna & 22. júl & Apoštol a evanjelista Ján & 27. december \\
\hline Apoštol Jakub & 25. júl & Sväté neviniatka & 28. december \\
\hline Anna, matka Márie & 26. júl & & \\
\hline
\end{tabular}

